\title{
The Impact of Nutritional Quality on the Students' Health
}

\section{Wpływ jakości odżywiania na stan zdrowia studentów}

D0I: $10.36740 / A B A L 202101107$

\author{
Grygoriy P. Griban', Vladyslav A. Smiianov², Natalia A. Lyakhova ${ }^{3}$, Pavlo P. Tkachenko ${ }^{4}$, Alla M. Harlinska ${ }^{1}$, \\ Nadya Yu. Dovgan' ${ }^{5}$, Roman P. Karpiuk6, Yurii A. Brytan ${ }^{7}$
}

'Zhytomyr Ivan Franko State University, Zhytomyr, Ukraine

${ }^{2}$ Sumy State University, Sumy, Ukraine

${ }^{3}$ Ukrainian Medical Stomatological Academy, Poltava, Ukraine

${ }^{4}$ Polissia National University, Zhytomyr, Ukraine

SUniversity of State Fiscal Service of Ukraine, Irpin, Ukraine

${ }^{6}$ Academy of Recreational Technologies and Law, Lutsk, Ukraine

${ }^{7}$ Ukrainian Engineering Pedagogical Academy, Kharkiv, Ukraine

\begin{abstract}
SUMMARY
Aim: To study the nutritional quality and its impact on the health of the students of higher education institutions.

Material and Methods: 647 students were interviewed. A questionnaire, which contains 17 questions and is aimed at studying the quality of students' nutrition, was created by authors. Experimental $(E G, n=60)$ and control ( $(G, n=60)$ groups were formed. The $E G$ included the students whose diet was rational while studying, the $C G$ included the students whose diet was irrational. The level of students' health was examined at the end of studying according to the methodology of professor G.L. Apanasenko.

Results: It was found that only $30.6 \%$ of students ate 3-4 times a day, $14.4 \%$ - twice a day, $49.8 \%$ did not follow any dietary regimen, and $7.9 \%$ of students would not eat breakfast at al $43.7 \%$ of male students and $53.3 \%$ of female students did not follow a dietary regimen at all. A comparative analysis of the physical health of students of EG and CG showed that among both male and female students, the students whose diet was rational had significantly better $(p<0.001)$ level of health.

Conclusions: It was determined that the majority of students had low nutritional quality while studying: nutrition was irrational, incomplete, and not varied. This does not contribute to a healthy lifestyle of modern students and can negatively affect the efficiency of their future professional activities.
\end{abstract}

Key words: nutritional quality, health, students

\section{STRESZCZENIE}

Cel: Celem pracy było zbadanie jakości odżywiania i jej wpływu na stan zdrowia studentów uczelni wyższych.

Materiał i metody: Dane uzyskano od 647 studentów. Autorzy stworzyli kwestionariusz zawierający 17 pytań, którego celem było zbadanie jakości odżywiania studentów. Wyróżniono dwie grupy: eksperymentalną $(E G, n=60)$ oraz kontrolną $(C G, n=60)$. Grupa EG obejmowała studentów, których dieta była racjonalna podczas nauki, a CG obejmowała studentów, których dieta była nieracjonalna. Na zakończenie nauki zbadano stan zdrowia studentów według metodyki prof. G. L. Apanasenko.

Wyniki: Stwierdzono, że tylko 30,6\% studentów jadło posiłki 3-4 razy dziennie, 14,4\% - dwa razy dziennie, 49,8\% nie stosowało żadnej diety, a 7,9\% studentów w ogóle nie jadło śniadania. 43,7\% studentów płci męskiej i 53,3\% studentek w ogóle nie przestrzegało diety. Analiza porównawcza stanu zdrowia fizycznego studentów EG i CG wykazała, że zarówno wśród studentów, jak i studentek, osoby których dieta była racjonalna, charakteryzowały się istotnie lepszym $(p<0,001)$ stanem zdrowia.

Wnioski: Stwierdzono, że większość studentów w trakcie studiów charakteryzowała się niską jakością odżywiania: żywienie było nieracjonalne, niepełne i niezróżnicowane. Zachowania te nie przyczyniają się do promocji zdrowego stylu życia współczesnych studentów i mogą negatywnie wpłynąć na efektywność ich przyszłych działań zawodowych.

Słowa kluczowe: jakość odżywiania, stan zdrowia, studenci 


\section{INTRODUCTION}

The profound socio-economic transformations that are taking place at the present stage of human evolution, the rapid growth of the world's population require a revision of the conceptual provisions of food security on a global scale. Nutrition is one of the most important forms of interaction between the human body and the environment, which provides the body with complex organic compounds and simple chemicals, minerals, and water. The organism needs them to build and regenerate cells and tissues and to cover the body's energy expenditure. The qualitative and quantitative composition of food significantly affects the state of human life [1-5].

In the conditions of the intense educational process, insufficient material security, constant change of environment, contradictory characteristics of food products, fast food, genetically modified products, grown in polluted ecological conditions, etc., the situation of the students' nutrition has significantly deteriorated. The traditional ideas about diets are not enough to maintain health and ensure a healthy lifestyle of students today. Nutrition is one of the main factors of a healthy lifestyle [6-8]. The development and formation of the organism, the state of health, and the level of efficiency depend on the state of nutrition [9-11]. Nutrition is a controlled factor that also affects all physiological, mental and social functions of people, shapes their life, influences the longevity, and creative and labor potential. The quality of nutrition has an effect on the mental and physical capacity of people, their development and growth, resistance to disease, and the ability to prolong life. Food should be varied, have a good appearance, and meet the needs and habits developed depending on a person's age, profession, living conditions, nationality, and other characteristics [12-14].

According to scientists [15-17], the energy spent in the course of life is restored only through food. Therefore, each student must have a conscious attitude to the diet, constantly update the knowledge, and take into account the recommendations of experts on the peculiarities of nutrition, based on specific living conditions. Thus, the teachers of physical education have to solve a number of problems, including the introduction of educational programs in the field of nutrition, promoting the basics of nutrition among students which is one of the links of a healthy lifestyle [18-20].

According to experts [21-23], all food sources with certain components, especially plants, can affect metabolic processes in the human body. Thus, cabbage contains substances that treat gastric and duodenal ulcers and have anti-cancer effects; carrot is used in cardiovascular and gallbladder diseases; table beet is widely used for anemia, etc. There is a number of plant products (sorrel, rhubarb, tomatoes, legumes, a very large number of medicinal plants), which can be harmful when consumed in large quantities. It should also be noted that cooking can enhance the beneficial qualities of food or destroy and sharply reduce harmful ones [24-26].

Scientists $[27,28]$ found that more than $60 \%$ of Ukrainians with a low level of total expenditures, mostly students, consume mainly potatoes and bread. Similar data were obtained in the research $[29,30]$, which confirmed that students' diets had the lack of biologically complete products of animal origin, fish, pectin and fiber, which regulate the activity of the large intestine. At the same time, the number of simple carbohydrates and animal fats was increased in the students' nutrition. A monotonous fat-carbohydrate diet leads to weight gain, accelerates the development of atherosclerosis, causes hypertension, insulin-dependent diabetes, and cancer, which eventually leads to disability.

It was proven that eating disorders throughout life lead to the typical diseases of the elderly, namely: cardiovascular system, stroke, diabetes, cancer, osteoporosis, cataracts, and glaucoma $[31,32]$. An unbalanced diet leads to the development of chronic non-communicable diseases (hypertension, coronary heart disease, diabetes). Insufficient protein and energy nutrition causes such infectious disease as tuberculosis. Inadequate food prevention also leads to the disease of endemic goiter and the growth of iron deficiency among girls and women of childbearing age. According to the WHO, rational and scientifically sound nutrition can prevent the development of cancer in the range of $35-50 \%[26,33]$. At the same time, a number of studies $[13,34,35]$ revealed many serious deficiencies in student nutrition. Therefore, $73.6 \%$ of students did not follow any food norms, $84.2 \%$ had no diet regimen, $95.7 \%$ did not follow food ration. Thus, the study of the nutritional quality of modern students and its impact on the health of young students in order to improve their lives is relevant.

\section{AIM}

The aim of this work is to study the nutritional quality and its impact on the health of the students of higher education institutions.

\section{MATERIAL AND METHODS}

The determination of the students' nutritional quality was conducted at Polissia National University and Zhytomyr Ivan Franko State University in 2014-2019. Thus, 647 students of different specialties between the ages of 17 and 23 were interviewed. A questionnaire created by the authors of this article was used for the survey in accordance with the requirements of the Code of Ethics of Polissia National University. The questionnaire contains 17 questions and is aimed at studying the nutrition quality of the students of higher education institutions of Ukraine as one of the main factors of their health, physical and mental capacity, and professional longevity (Attachment 1 ). The questionnaire was assessed by the experts in this field ( 5 professors and 7 associate professors) and was approved by the Academic Council of Polissia National University (Protocol No. 5 dated 29.08.2014). Consent to voluntary participation in the survey was obtained from all the students involved in the study.

Experimental (EG, $n=60)$ and control $(C G, n=60)$ groups were formed to study the impact of nutritional quality on the students' health. The experimental groups included the students ( 30 males and 30 females) whose diet was rational while studying at higher education institution, the control 
groups included the students ( 30 males and 30 females) whose diet was irrational. The level of students' health was examined at the end of studying at higher education institutions according to the methodology of the assessment of the somatic health level (by professor G. L. Apanasenko) based on the anthropometry indicators and the state of the cardiovascular system [36]. The health level was evaluated in points and it included the estimation of the body mass index (the ratio of body weight to body length), life index (the ratio of lung capacity to body weight), Robinson's index (a product of heart rate and systolic blood pressure), power index (the ratio of the wrist dynamometry to body weight) and heart rate recovery after a standard exercise (20 squats in $30 \mathrm{sec}$ ). Medical examinations were conducted by the doctors of medical centers of these higher education institutions.

The methods of investigation: questionnaire survey, methods of mathematical statistics, theoretical analysis and generalization of the scientific and methodological literature: 42 sources on the topic of the article from the scientometric databases PubMed, Scopus, Web of Science Core Collection and others were analyzed. The authenticity of the difference between the indicators of students of EG and CG was determined by Student's t-test and the dynamics of the indicators during studying were examined.

This study complies with the ethical standards of the Act of Ukraine “On Higher Education” No. 1556-VII dated 01.07.2014 and the Letter from the Ministry of Education and Science of Ukraine "On the Academic Plagiarism Prevention" No. 1/11-8681 dated 15.08.2018. Also, this study followed the regulations of the World Medical Association Declaration of Helsinki - ethical principles for medical research involving human subjects. Informed consent was received from all individuals who took part in this research.

\section{RESULTS}

One of the indicators of a healthy lifestyle, maintaining the health of students is a balanced diet, i. e. a properly organized supply of the body with well-prepared, nutritious, and tasty food that contains the optimal amount of various substances necessary for its development and functioning. Our detailed studies of the students' diet almost confirmed the previously obtained data $[1,3]$. It was indicated that only $30.6 \%$ of students ate $3-4$ times a day, $14.4 \%$ - twice a day, and $49.8 \%$ ate not following any regimens, and $7.9 \%$ of students would not eat breakfast at all, which is a violation of one of the requirements for a healthy lifestyle (Table 1).

The students, who do not follow a diet, often overeat, have an unbalanced diet, and do not follow the regimen. In general, the survey showed that male students followed diet better. Thus, $41.6 \%$ consumed food 3-4 times a day, whereas only $24.2 \%$ of female students followed the regimen. It should be noted that $43.7 \%$ of male students and $53.3 \%$ of female ones did not follow a diet at all. Eating twice a day and especially overeating in the evening can quickly lead to overweight, obesity, and general metabolic disorders.

The diet analysis of the students of different education departments also confirmed the general unsatisfactory picture in the nutrition system. Only $7.3 \%$ of the students of the sports department consumed food at a certain time, $14.5 \%$ - twice a day, $8.9 \%$ - would not eat breakfast, $46.8 \%$ - never followed the regime (Table 2).

Table 1. The students' assessment of their own diet $(n=647, \%)$

\begin{tabular}{|c|c|c|c|c|c|c|}
\hline \multirow{2}{*}{ Food consumption } & \multirow{2}{*}{ Gender } & \multicolumn{4}{|c|}{ The year of study } & \multirow{2}{*}{ Total \% } \\
\hline & & 1st & 2nd & 3rd & 4th & \\
\hline 3-4 times a day & $\begin{array}{c}\text { males } \\
\text { females } \\
\text { in total }\end{array}$ & $\begin{array}{l}42.8 \\
26.8 \\
35.8 \\
\end{array}$ & $\begin{array}{l}45.3 \\
24.1 \\
29.4 \\
\end{array}$ & $\begin{array}{l}40.0 \\
19.6 \\
27.9 \\
\end{array}$ & $\begin{array}{l}32.4 \\
24.7 \\
26.9 \\
\end{array}$ & $\begin{array}{l}41.6 \\
24.2 \\
30.6 \\
\end{array}$ \\
\hline Always at a certain time & $\begin{array}{c}\text { males } \\
\text { females } \\
\text { in total }\end{array}$ & $\begin{array}{l}6.7 \\
6.1 \\
6.4 \\
\end{array}$ & $\begin{array}{l}3.1 \\
3.7 \\
3.5 \\
\end{array}$ & $\begin{array}{l}2.9 \\
3.9 \\
3.5 \\
\end{array}$ & $\begin{array}{c}11.8 \\
1.2 \\
4.2 \\
\end{array}$ & $\begin{array}{l}5.9 \\
3.7 \\
4.5 \\
\end{array}$ \\
\hline 2 times a day & $\begin{array}{c}\text { males } \\
\text { females } \\
\text { in total }\end{array}$ & $\begin{array}{l}11.4 \\
15.9 \\
13.4\end{array}$ & $\begin{array}{l}15.6 \\
12.0 \\
12.9\end{array}$ & $\begin{array}{c}8.6 \\
17.6 \\
14.0\end{array}$ & $\begin{array}{l}14.7 \\
21.2 \\
19.3\end{array}$ & $\begin{array}{l}12.6 \\
15.4 \\
14.4\end{array}$ \\
\hline $\begin{array}{l}\text { Have dinner 2-3 hours before } \\
\text { going to sleep }\end{array}$ & $\begin{array}{c}\text { males } \\
\text { females } \\
\text { in total }\end{array}$ & $\begin{array}{l}4.8 \\
3.7 \\
4.3 \\
\end{array}$ & $\begin{array}{l}- \\
5.8 \\
4.3 \\
\end{array}$ & $\begin{array}{l}8.6 \\
7.8 \\
8.1 \\
\end{array}$ & $\begin{array}{c}14.7 \\
1.2 \\
5.0 \\
\end{array}$ & $\begin{array}{l}5.5 \\
4.6 \\
4.9 \\
\end{array}$ \\
\hline Eat right before going to sleep & $\begin{array}{c}\text { males } \\
\text { females } \\
\text { in total }\end{array}$ & $\begin{array}{l}3.8 \\
2.4 \\
3.2 \\
\end{array}$ & $\begin{array}{l}1.6 \\
3.7 \\
3.1 \\
\end{array}$ & $\begin{array}{l}8.6 \\
2.0 \\
4.7 \\
\end{array}$ & $\begin{array}{l}5.9 \\
1.2 \\
2.5 \\
\end{array}$ & $\begin{array}{l}4.2 \\
2.7 \\
3.2 \\
\end{array}$ \\
\hline Do not have breakfast & $\begin{array}{c}\text { males } \\
\text { females } \\
\text { in total }\end{array}$ & $\begin{array}{l}3.8 \\
6.1 \\
4.8 \\
\end{array}$ & $\begin{array}{l}4.7 \\
7.3 \\
6.7 \\
\end{array}$ & $\begin{array}{c}5.7 \\
21.6 \\
15.1 \\
\end{array}$ & $\begin{array}{c}5.9 \\
11.8 \\
10.1 \\
\end{array}$ & $\begin{array}{l}4.6 \\
9.8 \\
7.9 \\
\end{array}$ \\
\hline Do not follow the regimen & $\begin{array}{c}\text { males } \\
\text { females } \\
\text { in total }\end{array}$ & $\begin{array}{l}40.0 \\
51.2 \\
44.9\end{array}$ & $\begin{array}{l}37.5 \\
56.5 \\
51.8\end{array}$ & $\begin{array}{l}57.1 \\
54.9 \\
55.8\end{array}$ & $\begin{array}{l}52.9 \\
47.1 \\
48.7\end{array}$ & $\begin{array}{l}43.7 \\
53.3 \\
49.8\end{array}$ \\
\hline
\end{tabular}


Table 2. The assessment of the students' of different education departments diet $(n=647, \%)$

\begin{tabular}{|c|c|c|c|c|}
\hline \multirow{2}{*}{ Food consumption } & \multirow{2}{*}{ Gender } & \multicolumn{3}{|c|}{ Education departments } \\
\hline & & special & main & sports \\
\hline 3-4 times a day & $\begin{array}{c}\text { males } \\
\text { females } \\
\text { in total }\end{array}$ & $\begin{array}{l}37.7 \\
17.5 \\
24.7 \\
\end{array}$ & $\begin{array}{l}42.9 \\
27.1 \\
32.4 \\
\end{array}$ & $\begin{array}{l}42.3 \\
23.1 \\
32.3 \\
\end{array}$ \\
\hline Always at a certain time & $\begin{array}{l}\text { males } \\
\text { females } \\
\text { in total }\end{array}$ & $\begin{array}{l}3.8 \\
2.1 \\
2.7 \\
\end{array}$ & $\begin{array}{l}5.6 \\
3.6 \\
4.3 \\
\end{array}$ & $\begin{array}{l}8.5 \\
6.2 \\
7.3 \\
\end{array}$ \\
\hline 2 times a day & $\begin{array}{c}\text { males } \\
\text { females } \\
\text { in total }\end{array}$ & $\begin{array}{l}13.2 \\
16.5 \\
15.3 \\
\end{array}$ & $\begin{array}{l}11.1 \\
15.4 \\
13.9 \\
\end{array}$ & $\begin{array}{l}15.3 \\
13.8 \\
14.5 \\
\end{array}$ \\
\hline Have dinner 2-3 hours before going to sleep & $\begin{array}{c}\text { males } \\
\text { females } \\
\text { in total }\end{array}$ & $\begin{array}{c}15.1 \\
3.1 \\
7.3 \\
\end{array}$ & $\begin{array}{l}4.0 \\
5.7 \\
5.1 \\
\end{array}$ & $\begin{array}{l}- \\
3.1 \\
1.6 \\
\end{array}$ \\
\hline Eat right before going to sleep & $\begin{array}{c}\text { males } \\
\text { females } \\
\text { in total }\end{array}$ & $\begin{array}{l}5.7 \\
1.0 \\
2.7 \\
\end{array}$ & $\begin{array}{l}4.8 \\
2.4 \\
3.2 \\
\end{array}$ & $\begin{array}{l}1.7 \\
4.6 \\
3.2 \\
\end{array}$ \\
\hline Do not have breakfast & $\begin{array}{c}\text { males } \\
\text { females } \\
\text { in total }\end{array}$ & $\begin{array}{l}5.7 \\
6.2 \\
6.0 \\
\end{array}$ & $\begin{array}{l}4.8 \\
9.7 \\
8.0 \\
\end{array}$ & $\begin{array}{c}3.4 \\
13.8 \\
8.9 \\
\end{array}$ \\
\hline Do not follow the regimen & $\begin{array}{l}\text { males } \\
\text { females } \\
\text { in total }\end{array}$ & $\begin{array}{l}60.4 \\
56.7 \\
58.0\end{array}$ & $\begin{array}{l}29.7 \\
51.4 \\
47.5\end{array}$ & $\begin{array}{l}37.3 \\
55.4 \\
46.8\end{array}$ \\
\hline
\end{tabular}

Table 3. The assessment of the students' nutritional quality $(n=647, \%)$

\begin{tabular}{|c|c|c|c|c|c|c|}
\hline \multirow{2}{*}{ Nutrition indicators } & \multirow{2}{*}{ Gender } & \multicolumn{4}{|c|}{ The year of study } & \multirow{2}{*}{$\begin{array}{c}\text { Total } \\
\%\end{array}$} \\
\hline & & 1st & 2nd & 3rd & 4th & \\
\hline \multirow{3}{*}{ Often eat heavy, cold, and dry foods } & males & 46.7 & 51.6 & 54.3 & 50.0 & 49.6 \\
\hline & females & 48.7 & 47.1 & 60.8 & 49.4 & 49.6 \\
\hline & in total & 47.6 & 48.2 & 58.1 & 49.6 & 49.6 \\
\hline \multirow{3}{*}{ Often eat fat, bitter, sour, and oversalt foods } & males & 26.7 & 35.9 & 31.4 & 50.0 & 33.2 \\
\hline & females & 22.0 & 18.8 & 31.4 & 22.0 & 21.8 \\
\hline & in total & 24.6 & 23.1 & 31.4 & 30.0 & 26.0 \\
\hline \multirow{3}{*}{ Often eat fast food } & males & 39.0 & 35.9 & 51.4 & 32.4 & 39.1 \\
\hline & females & 32.9 & 36.6 & 15.7 & 22.4 & 30.3 \\
\hline & in total & 36.4 & 36.5 & 30.2 & 25.2 & 33.5 \\
\hline \multirow{3}{*}{$\begin{array}{l}\text { Drink strong tea and coffee more than } \\
2-3 \text { times a day }\end{array}$} & males & 31.4 & 20.3 & 20.0 & 29.4 & 26.5 \\
\hline & females & 32.9 & 38.7 & 35.3 & 29.4 & 35.2 \\
\hline & in total & 32.1 & 34.1 & 29.1 & 29.4 & 32.0 \\
\hline \multirow{3}{*}{ Like to have a substantial meal often } & males & 83.8 & 79.7 & 80.0 & 79.4 & 81.5 \\
\hline & females & 48.8 & 53.4 & 39.2 & 50.6 & 50.1 \\
\hline & in total & 68.4 & 60.0 & 55.8 & 58.8 & 61.7 \\
\hline \multirow{3}{*}{$\begin{array}{l}\text { Like to have a substantial meal sometimes } \\
\text { at a party }\end{array}$} & males & 9.5 & 6.3 & 17.1 & 8.8 & 9.7 \\
\hline & females & 11.0 & $\begin{array}{l}0.3 \\
22.0\end{array}$ & 33.3 & $\begin{array}{l}0.0 \\
29.4\end{array}$ & 22.7 \\
\hline & in total & 10.2 & 18.0 & 26.7 & 23.5 & 17.9 \\
\hline \multirow{3}{*}{ Have a hunger day } & males & 41.0 & 34.4 & 28.6 & 20.6 & 34.5 \\
\hline & females & 45.1 & 50.3 & 37.3 & 41.2 & 45.7 \\
\hline & in total & 42.8 & 46.3 & 33.7 & 35.3 & 41.6 \\
\hline \multirow{3}{*}{ Keep diets } & males & 4.8 & 1.6 & 2.9 & 8.8 & 4.2 \\
\hline & females & 26.8 & 35.1 & 17.6 & 12.9 & 26.7 \\
\hline & in total & 14.4 & 26.7 & 11.6 & 11.8 & 18.4 \\
\hline \multirow{3}{*}{ Confidently recognized their nutrition as poor } & males & 34.3 & 35.9 & 37.1 & 55.9 & 38.2 \\
\hline & females & 41.5 & 38.7 & 47.1 & 35.3 & 39.6 \\
\hline & in total & 37.4 & 38.0 & 43.0 & 41.2 & 39.1 \\
\hline
\end{tabular}


In the modern system of sports training, rational nutrition is considered as one of the leading factors that ensure high working capacity, adaptive reactions and efficiency of recovery processes during intense muscular activity $[37,38]$. Therefore, the nutrition of students who are actively involved in sports, participate in competitions, is characterized by the increased need for energy and additional nutrients, and, in turn, requires a rational and balanced diet.

The assessment of the quality of the students' nutrition showed that $49.6 \%$ of students ate cold and dry food quite often; $26 \%$ - ate fat and oversalt foods often; $33.5 \%$ - fast food products (vermicelli, chicken broths, etc.); more than $32 \%$ of students drank strong coffee and tea more than 2-3 times a day; $61.7 \%$ liked to have a substantial meal often, which accounts for $81.5 \%$ male students that is caused by constant hunger. In general, $39.1 \%$ of students confidently recognized their nutrition as poor, not meeting the basic requirements of the qualitative and quantitative composition of the diet (Table 3 ).

A significant place in the students' diet should be occupied by the first courses (broths, soups, and others), which have a certain physiological significance for humans. Their content of extractive and aromatic substances encourages the secretion of digestive juices, increased appetite, and assimilation of food. The taste of the first courses depends to some extent on the quality of the broth on which they are cooked (meat, bone, meat and bone, fish, mushroom, vegetable, dairy). Nitrogenous and nitrogen-free extractives give flavor to broths. Nitrogenous extractives include free amino acids, creatine, creatinine, and purine bases. Nitrogen-free extractives comprise glycogen, glucose, inositol, and lactic acid. The first courses should occupy a significant place in the menu of students. However, the obtained data showed that $21.5 \%$ of students only occasionally ate the first courses, $31.2 \%$ - once every 2-3 days, $37.7 \%$ - once a day and only $9.6 \%$ of students ate the first courses twice a day (Table 4).

A significant place in the diet of students is taken by cereals, which are an integral part of both the first and the second courses. Cereals are healthful and can replace quite expensive products in terms of nutritional value. In the conditions of radiation pollution, preference is given to oats and buckwheat, which contain a lot of complete protein, essential amino acids, vegetable fat, magnesium salts and polyphenols, which have anti-radiation effects. It was found that students rarely included oatmeal in their diet, it was dominant among cereals only for $4 \%$ of students. The preference was given to buckwheat $(69.2 \%)$ and rice $(52.7 \%)$, peas, millet, and wheat groats were also less popular (Table 5).

Seafood, unlike freshwater fish, is less contaminated with radionuclides, so sea fish and other seafood should be eaten daily. To eliminate iodine deficiency, one should eat seaweed, sea fish, mussels, squid, shrimp, and meat of marine animals. Seafood is also an important source of fats, proteins, vitamins, and minerals. Unfortunately, the students' consumption of fish and seafood was very low. Only 5.3\% of students used them in sufficient quantities, and 35.1\% - 1-2 times a week, $35.6 \%$ - very rarely (Table 6).

Low consumption of milk and dairy products causes calcium deficiency. The sulfur-containing amino acids and calcium, which have a radioprotective effect, make cheese and cottage cheese indispensable in the daily diet. In addition, dairy products are a source of protein, fat, carbohydrates, vitamins, minerals, etc. Currently, the situation with dairy products in the diet of students is quite acute. The students like to consume milk, various dairy products, cheeses, but, unfortunately, they are often absent in student canteens, and are quite expensive in shops. The studies showed that only $11 \%$ of students could afford to consume milk and dairy products 2-3 times a day and in sufficient quantities, $18.5 \%$ - consumed only 1 time a day, and the rest of the students did not include these products in their diet in sufficient quantities. Almost a third of students $(27.1 \%)$ consumed dairy products 1-2 times a week, and $27.5 \%$ - very rarely (Table 7).

Research data $[6,8]$ showed that the consumption of fresh vegetables in the winter-spring period was unsatisfactory for $74.4 \%$ of students, and met the need for only some of them by $25-65 \%$. The studies confirmed that only $11 \%$ of students consumed fresh vegetables and fruits in sufficient quantities and in a wide range in winter, and $70.6 \%$ - consumed them mainly once a day and only locally-produced ones (Table 8). Vegetables contain non-starch carbohydrates (alginates,

Table 4. The frequency of the students' consumption of the first courses ( $n=647, \%)$

\begin{tabular}{|c|c|c|c|c|c|c|}
\hline \multirow{2}{*}{ The number of times } & \multirow{2}{*}{ Gender } & \multicolumn{4}{|c|}{ The year of study } & \multirow{2}{*}{$\begin{array}{c}\text { Total } \\
\%\end{array}$} \\
\hline & & 1st & 2nd & 3rd & 4th & \\
\hline \multirow{3}{*}{ Twice a day } & males & 18.1 & 7.8 & 14.3 & 2.9 & 12.6 \\
\hline & females & 17.1 & 6.3 & 5.9 & 3.5 & 7.8 \\
\hline & in total & 17.6 & 6.7 & 9.3 & 3.4 & 9.6 \\
\hline \multirow{3}{*}{ Once a day } & males & 45.7 & 42.2 & 51.4 & 53.0 & 46.6 \\
\hline & females & 29.3 & 34.6 & 31.3 & 31.8 & 32.5 \\
\hline & in total & 38.5 & 36.5 & 39.5 & 37.8 & 37.7 \\
\hline \multirow{3}{*}{ One every 2-3 days } & males & 21.0 & 21.9 & 25.7 & 26.5 & 22.7 \\
\hline & females & 22.0 & 38.2 & 47.1 & 38.8 & 36.2 \\
\hline & in total & 21.4 & 34.1 & 38.4 & 35.3 & 31.2 \\
\hline \multirow{3}{*}{ Sometimes } & males & 15.2 & 28.1 & 8.6 & 17.6 & 18.1 \\
\hline & females & 31.6 & 20.9 & 15.7 & 25.9 & 23.5 \\
\hline & in total & 22.5 & 22.7 & 12.8 & 23.5 & 21.5 \\
\hline
\end{tabular}


Table 5. Cereals that dominate in the diet of students $(n=647, \%)$

\begin{tabular}{|c|c|c|c|c|c|c|}
\hline \multirow{2}{*}{ The name of cereals } & \multirow{2}{*}{ Gender } & \multicolumn{4}{|c|}{ The year of study } & \multirow{2}{*}{ Total \% } \\
\hline & & 1st & 2nd & 3rd & 4th & \\
\hline Buckwheat & $\begin{array}{c}\text { males } \\
\text { females } \\
\text { in total }\end{array}$ & $\begin{array}{l}66.7 \\
69.5 \\
67.9\end{array}$ & $\begin{array}{l}68.8 \\
69.6 \\
69.4 \\
\end{array}$ & $\begin{array}{l}80.0 \\
70.6 \\
74.4\end{array}$ & $\begin{array}{l}82.4 \\
61.2 \\
67.2\end{array}$ & $\begin{array}{l}71.4 \\
68.0 \\
69.2 \\
\end{array}$ \\
\hline Rice & $\begin{array}{c}\text { males } \\
\text { females } \\
\text { in total }\end{array}$ & $\begin{array}{l}52.4 \\
54.9 \\
53.5 \\
\end{array}$ & $\begin{array}{l}46.9 \\
52.4 \\
51.0 \\
\end{array}$ & $\begin{array}{l}51.4 \\
54.9 \\
53.5 \\
\end{array}$ & $\begin{array}{l}58.8 \\
55.3 \\
56.3 \\
\end{array}$ & $\begin{array}{l}51.7 \\
53.3 \\
52.7 \\
\end{array}$ \\
\hline Peas & $\begin{array}{c}\text { males } \\
\text { females } \\
\text { in total }\end{array}$ & $\begin{array}{l}15.2 \\
13.4 \\
14.4 \\
\end{array}$ & $\begin{array}{c}29.7 \\
6.8 \\
12.5 \\
\end{array}$ & $\begin{array}{c}28.6 \\
5.9 \\
15.1 \\
\end{array}$ & $\begin{array}{c}20.6 \\
7.1 \\
10.9 \\
\end{array}$ & $\begin{array}{c}21.8 \\
8.1 \\
13.1 \\
\end{array}$ \\
\hline Millet & $\begin{array}{c}\text { males } \\
\text { females } \\
\text { in total }\end{array}$ & $\begin{array}{l}2.9 \\
4.9 \\
3.7 \\
\end{array}$ & $\begin{array}{l}7.8 \\
4.2 \\
5.1 \\
\end{array}$ & $\begin{array}{c}22.9 \\
- \\
9.3 \\
\end{array}$ & $\begin{array}{l}11.8 \\
2.4 \\
5.0 \\
\end{array}$ & $\begin{array}{l}8.4 \\
3.4 \\
5.3 \\
\end{array}$ \\
\hline Wheat groats & $\begin{array}{c}\text { males } \\
\text { females } \\
\text { in total }\end{array}$ & $\begin{array}{l}7.6 \\
6.1 \\
7.0 \\
\end{array}$ & $\begin{array}{l}10.9 \\
13.6 \\
12.9 \\
\end{array}$ & $\begin{array}{c}34.3 \\
5.9 \\
17.4 \\
\end{array}$ & $\begin{array}{l}20.6 \\
10.6 \\
13.4 \\
\end{array}$ & $\begin{array}{l}14.3 \\
10.5 \\
11.9 \\
\end{array}$ \\
\hline Pearl barley & $\begin{array}{c}\text { males } \\
\text { females } \\
\text { in total }\end{array}$ & $\begin{array}{c}6.7 \\
14.6 \\
10.2 \\
\end{array}$ & $\begin{array}{l}7.8 \\
7.9 \\
7.8 \\
\end{array}$ & $\begin{array}{l}17.1 \\
3.9 \\
9.3 \\
\end{array}$ & $\begin{array}{l}8.8 \\
5.9 \\
6.7 \\
\end{array}$ & $\begin{array}{l}8.8 \\
8.3 \\
8.5 \\
\end{array}$ \\
\hline Oatmeal & $\begin{array}{c}\text { males } \\
\text { females } \\
\text { in total }\end{array}$ & $\begin{array}{l}3.8 \\
2.4 \\
3.2 \\
\end{array}$ & $\begin{array}{l}6.3 \\
2.6 \\
3.5 \\
\end{array}$ & $\begin{array}{l}8.6 \\
5.9 \\
7.0 \\
\end{array}$ & $\begin{array}{l}5.9 \\
3.5 \\
4.2 \\
\end{array}$ & $\begin{array}{l}5.5 \\
3.2 \\
4.0 \\
\end{array}$ \\
\hline Others & $\begin{array}{l}\text { males } \\
\text { females } \\
\text { in total }\end{array}$ & $\begin{array}{c}8.6 \\
13.4 \\
10.7\end{array}$ & $\begin{array}{l}20.3 \\
11.5 \\
13.7\end{array}$ & $\begin{array}{l}11.4 \\
7.8 \\
9.3\end{array}$ & $\begin{array}{l}29.4 \\
15.3 \\
19.3\end{array}$ & $\begin{array}{l}15.1 \\
12.2 \\
13.3\end{array}$ \\
\hline
\end{tabular}

Table 6. The frequency of the students' consumption of fish and seafood ( $n=647, \%)$

\begin{tabular}{|c|c|c|c|c|c|c|}
\hline \multirow{2}{*}{ The number of times } & \multirow{2}{*}{ Gender } & \multicolumn{4}{|c|}{ The year of study } & \multirow{2}{*}{$\begin{array}{c}\text { Total } \\
\%\end{array}$} \\
\hline & & 1st & 2nd & 3rd & 4th & \\
\hline Once a day & $\begin{array}{c}\text { males } \\
\text { females } \\
\text { in total }\end{array}$ & $\begin{array}{l}10.5 \\
4.9 \\
8.0 \\
\end{array}$ & $\begin{array}{l}10.9 \\
14.1 \\
13.3 \\
\end{array}$ & $\begin{array}{l}5.7 \\
7.8 \\
7.0 \\
\end{array}$ & $\begin{array}{c}14.7 \\
8.2 \\
10.1 \\
\end{array}$ & $\begin{array}{l}10.5 \\
10.3 \\
10.4 \\
\end{array}$ \\
\hline 2-3 times a day & $\begin{array}{c}\text { males } \\
\text { females } \\
\text { in total }\end{array}$ & $\begin{array}{l}4.8 \\
4.9 \\
4.8 \\
\end{array}$ & $\begin{array}{l}7.8 \\
8.4 \\
8.2 \\
\end{array}$ & $\begin{array}{c}- \\
3.9 \\
2.2\end{array}$ & $\begin{array}{l}2.9 \\
1.2 \\
1.7 \\
\end{array}$ & $\begin{array}{l}4.6 \\
5.6 \\
5.3 \\
\end{array}$ \\
\hline Once every 2 days & $\begin{array}{c}\text { males } \\
\text { females } \\
\text { in total }\end{array}$ & $\begin{array}{c}9.5 \\
13.4 \\
11.2 \\
\end{array}$ & $\begin{array}{l}14.1 \\
16.8 \\
16.1 \\
\end{array}$ & $\begin{array}{c}14.3 \\
2.0 \\
7.0 \\
\end{array}$ & $\begin{array}{l}11.8 \\
11.8 \\
11.8 \\
\end{array}$ & $\begin{array}{l}11.8 \\
13.2 \\
12.7 \\
\end{array}$ \\
\hline 1-2 times a week & $\begin{array}{c}\text { males } \\
\text { females } \\
\text { in total }\end{array}$ & $\begin{array}{l}36.2 \\
28.0 \\
32.6 \\
\end{array}$ & $\begin{array}{l}37.5 \\
26.7 \\
29.5 \\
\end{array}$ & $\begin{array}{l}45.7 \\
39.2 \\
41.9 \\
\end{array}$ & $\begin{array}{l}38.2 \\
50.6 \\
47.0 \\
\end{array}$ & $\begin{array}{l}38.2 \\
33.5 \\
35.1 \\
\end{array}$ \\
\hline Sometimes & $\begin{array}{c}\text { males } \\
\text { females } \\
\text { in total }\end{array}$ & $\begin{array}{l}39.0 \\
48.8 \\
43.4 \\
\end{array}$ & $\begin{array}{l}29.7 \\
34.0 \\
32.9 \\
\end{array}$ & $\begin{array}{l}34.3 \\
47.1 \\
41.9 \\
\end{array}$ & $\begin{array}{l}32.4 \\
28.2 \\
29.4 \\
\end{array}$ & $\begin{array}{l}34.9 \\
37.4 \\
36.5 \\
\end{array}$ \\
\hline
\end{tabular}

polysaccharides, dietary fiber, pectin), which have radioprotective properties, so their consumption in the required amount is a prerequisite for the proper nutrition of young students. Fresh fruits and vegetables, fruit and vegetable juices, jellies, beverages containing a lot of pectins should be used in the preventive nutrition of students who live in a polluted environment and also come into contact with inorganic compounds, heavy metals or radionuclides.

The studies also showed that almost all students consumed excessive amounts of pure carbohydrates (sugar, jams, etc.), which are desirable to be replaced with fruits, vegetables, cereals, honey, etc. The consumption of sweets for breakfast, lunch, and dinner was typical for $12.8 \%$ of students (Table 9).

Therefore, it can be summarized that there is a pronounced deficiency of meat, fish, milk and dairy products, fresh vegetables and fruits in the diet of students. The insufficient quantity and small range of products containing vitamins A, C, B2 are consumed. Polynutrietic malnutrition or socalled latent hunger is common. From a physiological point of view, the nutrition of students is poor, in terms of age, 
Table 7. The frequency of students' consumption of dairy products $(n=647, \%)$

\begin{tabular}{|c|c|c|c|c|c|c|}
\hline \multirow{2}{*}{ The number of times } & \multirow{2}{*}{ Gender } & \multicolumn{4}{|c|}{ The year of study } & \multirow{2}{*}{$\begin{array}{c}\text { Total } \\
\%\end{array}$} \\
\hline & & 1st & 2nd & 3rd & 4th & \\
\hline Once a day & $\begin{array}{c}\text { males } \\
\text { females } \\
\text { in total }\end{array}$ & $\begin{array}{l}21.9 \\
14.6 \\
18.7\end{array}$ & $\begin{array}{l}23.3 \\
17.8 \\
19.2\end{array}$ & $\begin{array}{l}31.4 \\
11.8 \\
19.8\end{array}$ & $\begin{array}{l}23.5 \\
12.9 \\
16.1\end{array}$ & $\begin{array}{l}23.9 \\
15.4 \\
18.5\end{array}$ \\
\hline 2-3 times a day & $\begin{array}{c}\text { males } \\
\text { females } \\
\text { in total }\end{array}$ & $\begin{array}{l}17.1 \\
11.0 \\
14.4\end{array}$ & $\begin{array}{c}14.1 \\
9.4 \\
10.6\end{array}$ & $\begin{array}{c}5.7 \\
- \\
2.3\end{array}$ & $\begin{array}{l}11.8 \\
12.9 \\
12.6\end{array}$ & $\begin{array}{c}13.9 \\
9.3 \\
11.0\end{array}$ \\
\hline Once every 2 days & $\begin{array}{c}\text { males } \\
\text { females } \\
\text { in total }\end{array}$ & $\begin{array}{c}15.2 \\
9.8 \\
12.8 \\
\end{array}$ & $\begin{array}{l}18.8 \\
14.7 \\
15.7 \\
\end{array}$ & $\begin{array}{l}11.4 \\
17.6 \\
15.1 \\
\end{array}$ & $\begin{array}{l}35.3 \\
16.5 \\
21.8\end{array}$ & $\begin{array}{l}18.5 \\
14.4 \\
15.9\end{array}$ \\
\hline 1-2 times a week & $\begin{array}{c}\text { males } \\
\text { females } \\
\text { in total }\end{array}$ & $\begin{array}{l}17.1 \\
32.9 \\
24.2\end{array}$ & $\begin{array}{l}21.9 \\
26.2 \\
25.1\end{array}$ & $\begin{array}{l}28.6 \\
39.2 \\
34.9 \\
\end{array}$ & $\begin{array}{l}11.8 \\
37.6 \\
30.3 \\
\end{array}$ & $\begin{array}{l}19.3 \\
31.6 \\
27.1 \\
\end{array}$ \\
\hline Sometimes & $\begin{array}{c}\text { males } \\
\text { females } \\
\text { in total }\end{array}$ & $\begin{array}{l}28.7 \\
31.7 \\
29.9\end{array}$ & $\begin{array}{l}21.9 \\
31.9 \\
29.4\end{array}$ & $\begin{array}{l}22.9 \\
31.4 \\
27.9\end{array}$ & $\begin{array}{l}17.6 \\
20.1 \\
19.2\end{array}$ & $\begin{array}{l}24.4 \\
29.3 \\
27.5\end{array}$ \\
\hline
\end{tabular}

Table 8. The frequency of the students' consumption of fresh fruits and vegetables in winter $(n=647, \%)$

\begin{tabular}{|c|c|c|c|c|c|c|}
\hline \multirow{2}{*}{ The number of times } & \multirow{2}{*}{ Gender } & \multicolumn{4}{|c|}{ The year of study } & \multirow{2}{*}{ Total \% } \\
\hline & & 1st & 2nd & $3 r d$ & 4th & \\
\hline Once a day & $\begin{array}{c}\text { males } \\
\text { females } \\
\text { in total }\end{array}$ & $\begin{array}{l}69.5 \\
71.9 \\
70.6 \\
\end{array}$ & $\begin{array}{l}71.9 \\
66.5 \\
67.8 \\
\end{array}$ & $\begin{array}{l}80.0 \\
72.5 \\
75.6 \\
\end{array}$ & $\begin{array}{l}67.7 \\
75.3 \\
73.1 \\
\end{array}$ & $\begin{array}{l}71.4 \\
70.2 \\
70.6 \\
\end{array}$ \\
\hline 2-3 times a day & $\begin{array}{c}\text { males } \\
\text { females } \\
\text { in total }\end{array}$ & $\begin{array}{l}18.1 \\
12.2 \\
15.5 \\
\end{array}$ & $\begin{array}{l}25.0 \\
20.9 \\
22.0 \\
\end{array}$ & $\begin{array}{l}17.1 \\
15.7 \\
16.3 \\
\end{array}$ & $\begin{array}{l}23.5 \\
14.1 \\
16.8 \\
\end{array}$ & $\begin{array}{l}20.6 \\
17.1 \\
18.4 \\
\end{array}$ \\
\hline Once every 2 days & $\begin{array}{c}\text { males } \\
\text { females } \\
\text { in total }\end{array}$ & $\begin{array}{l}12.4 \\
15.9 \\
13.9 \\
\end{array}$ & $\begin{array}{c}3.1 \\
12.6 \\
10.2\end{array}$ & $\begin{array}{c}2.9 \\
11.8 \\
8.1\end{array}$ & $\begin{array}{c}8.8 \\
10.6 \\
10.1\end{array}$ & $\begin{array}{c}8.0 \\
12.7 \\
11.0\end{array}$ \\
\hline
\end{tabular}

Table 9. The frequency of the students' consumption of sweets ( $n=647, \%)$

\begin{tabular}{|c|c|c|c|c|c|c|}
\hline \multirow{2}{*}{ The number of times } & \multirow{2}{*}{ Gender } & \multicolumn{4}{|c|}{ The year of study } & \multirow{2}{*}{$\begin{array}{c}\text { Total } \\
\%\end{array}$} \\
\hline & & 1st & 2nd & 3 rd & 4th & \\
\hline 3-4 times a day & $\begin{array}{c}\text { males } \\
\text { females } \\
\text { in total }\end{array}$ & $\begin{array}{l}21.0 \\
11.0 \\
16.6 \\
\end{array}$ & $\begin{array}{c}9.4 \\
13.6 \\
12.5 \\
\end{array}$ & $\begin{array}{l}5.7 \\
7.8 \\
7.0 \\
\end{array}$ & $\begin{array}{l}14.7 \\
10.6 \\
11.8 \\
\end{array}$ & $\begin{array}{l}14.7 \\
11.7 \\
12.8 \\
\end{array}$ \\
\hline $1-2$ times a day & $\begin{array}{c}\text { males } \\
\text { females } \\
\text { in total }\end{array}$ & $\begin{array}{l}61.9 \\
61.0 \\
61.5 \\
\end{array}$ & $\begin{array}{l}60.9 \\
55.5 \\
56.9 \\
\end{array}$ & $\begin{array}{l}74.3 \\
74.6 \\
74.4 \\
\end{array}$ & $\begin{array}{l}58.8 \\
58.8 \\
58.8 \\
\end{array}$ & $\begin{array}{l}63.0 \\
59.7 \\
60.9 \\
\end{array}$ \\
\hline Try not to eat sweets & $\begin{array}{l}\text { males } \\
\text { females } \\
\text { in total }\end{array}$ & $\begin{array}{l}17.1 \\
28.0 \\
21.9\end{array}$ & $\begin{array}{l}29.7 \\
30.9 \\
30.6\end{array}$ & $\begin{array}{l}20.0 \\
17.6 \\
18.6\end{array}$ & $\begin{array}{l}26.5 \\
30.6 \\
29.4\end{array}$ & $\begin{array}{l}22.3 \\
28.6 \\
26.3\end{array}$ \\
\hline
\end{tabular}

Table 10. The level of health of the EG and CG students at the end of studying at HEl (Mean $\pm S D . n=120$ )

\begin{tabular}{|c|c|c|c|c|c|c|}
\hline \multirow{2}{*}{ Indicators } & \multicolumn{3}{|c|}{ Males $(n=60)$} & \multicolumn{3}{|c|}{ Females $(n=60)$} \\
\hline & $E G(n=30)$ & $C G(n=30)$ & $\mathbf{p}$ & $E G(n=30)$ & CG $(n=30)$ & $\mathbf{p}$ \\
\hline Body mass index, $\mathrm{kg} / \mathrm{m}^{2}$ & $22.8 \pm 0.22$ & $23.6 \pm 0.24$ & $<0.05$ & $20.7 \pm 0.25$ & $22.1 \pm 0.26$ & $<0.01$ \\
\hline Life index, $\mathrm{ml} / \mathrm{kg}$ & $58.9 \pm 1.19$ & $54.8 \pm 1.21$ & $<0.05$ & $51.6 \pm 1.27$ & $47.2 \pm 1.30$ & $<0.05$ \\
\hline Power index, \% & $61.3 \pm 1.04$ & $56.4 \pm 1.12$ & $<0.01$ & $48.8 \pm 1.09$ & $40.2 \pm 1.14$ & $<0.001$ \\
\hline Robinson's index. s.u. & $84.7 \pm 1.18$ & $90.0 \pm 1.26$ & $<0.01$ & $79.1 \pm 1.23$ & $83.4 \pm 1.29$ & $<0.01$ \\
\hline $\begin{array}{l}\text { Heart rate recovery after } 20 \text { squats } \\
\text { in } 30 \mathrm{sec} \text {, sec }\end{array}$ & $112.4 \pm 2.38$ & $127.1 \pm 2.51$ & $<0.001$ & $119.5 \pm 2.87$ & $136.2 \pm 3.02$ & $<0.01$ \\
\hline The level of physical health, points & $6.07 \pm 0.61$ & $2.94 \pm 0.48$ & $<0.001$ & $6.51 \pm 0.59$ & $3.17 \pm 0.54$ & $<0.001$ \\
\hline
\end{tabular}


gender, educational and physical activity, participation in competitions and recreation, and so on.

To study the impact of the quality of students' nutrition on the state of their health while studying at higher education institutions (HEI), we conducted a comparative analysis of the level of physical health of students whose nutrition was rational (experimental groups) and irrational (control groups), using the G. L. Apanasenko's method (Table 10).

The analysis of the body mass index indicated that the average indicators of both female and male students were better authentically at the end of studying at HEI. The difference in the indicators between EG and CG was authentic and accounts for $0.8 \mathrm{~kg} / \mathrm{m}^{2}$ for male students $(\mathrm{p}<0.05)$, and $1.4 \mathrm{~kg} / \mathrm{m}^{2}$ for female students $(\mathrm{p}<0.01)$. The investigation of life index showed that it was $4.1 \mathrm{ml} / \mathrm{kg}$ and $4.4 \mathrm{ml} / \mathrm{kg}$ better respectively in both experimental groups in comparison with control groups authentically $(\mathrm{p}<0.05)$. A similar tendency was observed during the analysis of the other indices: power index, Robinson's index, heart rate recovery after 20 squats in $30 \mathrm{sec}$ - the indicators of the EG students (both male and female) were better than the indicators of the CG students authentically $(\mathrm{p}<0.05-0.001)$ (Table 10). The analysis of the physical health level defined that the health level was better authentically $(\mathrm{p}<0.001)$ in both experimental groups than in control ones by 3.13 and 3,34 points respectively that emphasises the necessity to eat rationally to preserve the health. The conducted analysis proved the importance of the nutritional quality for the students' health improvement and the efficient studying and future professional activity.

\section{DISCUSSION}

The scientists $[13,15]$ mention that nutrition is of high importance for some groups of people from the health-improving perspective, and it can influence the life of entire nations from the social perspective. The history of cooking goes back to the distant past. Over the centuries, all peoples, regardless of their degree of social and cultural development, considered the process of eating to be not only the satisfaction of physiological needs, but also the part of the general culture.

Over the past 80 years, the world's population has almost tripled. According to experts, the world's population will increase by 3.7 billion people by 2030 , food demand will doubled, and energy consumption tripled $[21,27]$. Thus, we can already conclude that, despite the achievements of science and technology, tensions in society will increase, and the state of food and energy security of society will play a leading role. Today, every sixth person on the planet goes to bed hungry, 15-20 million children die each year from malnutrition; more than 30 million people even from relatively prosperous countries with economic systems in transition have poor nutritional quality [13].

In recent years, the deteriorating economic and environmental situation in Ukraine and around the world is constantly decreasing the quality of agricultural products and food in terms various indicators. There are changes in the content of protein and gluten in cereals, which negatively affects the quality of flour and, consequently, bread products. Growing of agricultural plants by intensive technologies, with the use of mineral fertilizers and agrochemicals, the introduction of genetic engineering has led to a decrease in the quality of food raw materials. On the other hand, food is exposed to biogenic and human-induced contaminants. The processing of agricultural raw materials and food production use a large number of food additives, which do not always have a positive effect on human health. Along with the decline in technological qualities and nutritional value, there is deterioration in the environmental safety of foods. The violation of the technology of using pesticides even in small doses, as well as the use of outdated technologies has led to the fact that the food contains a high amount of pesticides and heavy metals in a large number of domestic farms of various forms of ownership. This is confirmed by frequent food poisonings, especially of low-income people. According to experts, more than $60 \%$ of toxic substances enter the human body with food [26]. The current situation in the food markets of leading European countries and the United States indicates a special interest of consumers in healthy and wholesome food. The increased standard of living in developed countries changed also attitudes toward food. Consumers are becoming more conscious of their diet, willing not only to eat properly but also to eliminate any health risks.

Our data based on the results of the research show that the structure of students' nutrition is irrational, which is a risk factor for the future development of such diseases as hypertension, cholecystitis, diabetes, obesity, cancer, and others. It was found that, on the one hand, the main reasons for the low quality of student nutrition are low material and purchasing power of students and their parents and, on the other hand, insufficient level of knowledge, nutrition culture, non-compliance with the diet. This determines the need to improve the quality of the students' nutrition. The results of these studies require the teachers of physical education departments and other HEI structures to conduct educational work among students, as well as to establish a nutrition system at HEI, to plan classes, taking into account the time for students' eating.

The results obtained complement and extend the findings of many studies [39-42].

\section{CONCLUSIONS}

According to the results of the research conducted, it was determined that only $30.6 \%$ of students ate 3-4 times a day, $14.4 \%$ - twice a day, $49.8 \%$ did not follow any regimen, and $7.9 \%$ of students would not have breakfast at all, which is a violation of one of the requirements of a healthy lifestyle. It was defined that $43.7 \%$ of male students and $53.3 \%$ of female did not follow diet at all. In addition, the study designated that $49.6 \%$ of students often ate cold and dry food; $33.5 \%$ - convenience food (vermicelli, chicken broths, etc.); $26 \%$ ate fat and oversalt foods often; more than $32 \%$ of students drank strong coffee and tea more than 2-3 times a day. A comparative analysis of the physical health of students whose 
diet was rational and irrational during their studies showed that among both male and female students, the students whose diet was rational had significantly better $(p<0.001)$ level of health. The difference accounts for 3.13 points in the group of male students and 3,34 points in the group of female students that emphasises the necessity to improve the nutritional quality to preserve students' health.

It was determined that the nutritional quality of the majority of students (both male and female) was low while studying at higher education institutions: their nutrition was irrational, incomplete and not varied. There was a severe deficiency of meat, fish, milk and dairy products, fresh vegetables, and fruits indicated in the diet of students. Their diet included an insufficient amount of foods that contain the necessary vitamins and minerals. The principles of achieving energy balance and the ratio between the main nutrients - proteins, fats, and carbohydrates - were not taken into account. Most students were defined to consume the excessive amount of animal fat and insufficient consumption of plant fat that leads to growth disorders, the decline of the organism's resistance, and skin disorders. All this do not contribute to a healthy lifestyle of modern students and can have a negative impact on the efficiency of their future professional activity.The prospects for future research are aimed at studying the ways to improve the students' diet while studying at HEI.

\section{References}

1. Danylenko HM, Sotnikova-Meleshkina ZhV, Smiianov VA. The impact of an educational institution on development of healthy lifestyle skills for prevention of obesity in adolescents. Wiad. Lek. 2020;73(5): 978-982. doi:10.36740/WLek202005126.

2. Prontenko K, Griban G, Dovgan N et al. Students'health and its interrelation with physical fitness level. Sport Mont. 2019;17(3):41-46. doi 10.26773/ smj.191018.

3. Pishkovtsi A-MM, Rohach IM, Keretsman A0, Palko Al, Tsyhyka OI. State of dental health of children in Uzhhorod and the way of their nutrition. Wiad. Lek. 2020; 73(1): 73-77. doi:10.36740/WLek202001113.

4. Irina A, Holovanova, Natalia A. Lyakhova, Olga V. Sheshukova et al. Studying the skills attitudes on factors affecting dental health of children. Wiad. Lek.2018;71 (3):740-747.

5. Olha V, Sheshukova, Valentina P. Trufanova, Tetiana V. Polishchuk et al. Monitoring of efficiency of dental caries management in children's temporary teeth throughout poltava oblast. Wiad. Lek. 2018; 71(3):761-767.

6. Vilenskiy MY. Sotsialno-psihologicheskie determinantyi formirovaniya zdorovogo obraza zhizni [Socio-psychological determinants of a healthy lifestyle]. Teoriya i praktika fizicheskoy kulturyi. 1994;9: 9-11. (In Russian).

7. Prysiazhniuk S, Oleniev D, Tiazhyna A et al. Formation of heath preserving competence of students of higher educational institutions of information technologies specialties. Inter J Applied Exercise Physiol. 2019;8(3.1):283292. doi:10.26655/IJAEP.2019.10.1.

8. Turchyna NS, Savosko SI, Cherenko TM, Ribalko SL, Starosyla DB. Ultrastructural features of herpesvirus-induced aortic intima damage in mice fed the high-fat diet. Wiad. Lek. 2020;73(3):498-503. doi:10.36740/ WLek202003117.

9. PanayotovV. Influence of food substitutes' diet on weight reduction in physically active obese people. Sport Mont. 2014;12(40-41-42):105-112.
10. Mohammed M, Al-Qahtani M. Effects of 12 weeks aerobic exercise with a diet regimen on the glycemic control and cardiovascular health of boys with type 1 diabetes mellitus. International Journal of Applied Exercise Physiology. 2019;8(3): 49-58.Available from: http://www.ijaep.com/index. php/IJAE/article/view/518.

11. Gruzieva T, Galiienko L, Pelo I et al. Health and lifestyle of students'youth: status, problems and ways of solution. Wiad Lek. 2018;71(9):1753-1758.

12. Essaw $E$, Moses MO, Afrifa D et al. Physical activity patterns and dietary habits of undergraduate students. Baltic Journal of Health and Physical Activity. 2019;11(1):115-123. doi:10.29359/BJHPA.11.1.12.

13. Layko PA, Babienko MF, BuzovskiyEA. Bezpeka harchuvannya -zaporukazdorov'ya [Food security is the key to good health]. Ekonomika EPK. 2004;10:37-46. (In Ukrainian).

14. Prontenko K, Griban G, Aloshyna A et al. The physical development and functional state as the important components of the students' health. Wiad. Lek. 2019;72(12a):2348-2353. doi:10.36740/WLek201912115.

15. Smith KJ, Blizzard L, McNaughton SA et al. Takeaway food consumption and cardio-metabolic risk factors in young adults. Eur J Clin Nutrition. 2012;66:577-584. http://doi.org/10.1038/ejcn.2011.202.

16. Griban G, Lyakhova N, Tymoshenko 0. Current state of students' health and its improvement in the process of physical education. Wiad. Lek. 2020;73(7):1438-1447. doi:10.36740/WLek202007124.

17. Mozolev 0, Bloshchynsky I, Alieksieiev 0 et al. Influence of modern fitness technologies on the state of health and development of motor abilities of 17-19-year-old female students. J Phys Education Sport. 2019;19(3):917924. doi:10.7752/jpes.2019.s3132.

18. Griban G, Prontenko K, Yavorska T et al. Non-traditional means of physical training in middle school physical education classes. Inter J Appl Exer Physiol. 2019;8(3.1):224-232. doi:10.26655/IJAEP.2019.10.1.

19. Shkola 0, Griban G, Prontenko K et al. Formation of valuable orientations in youth during physical training. Inter J Appl Exer Physiol. 2019;8(3.1): 264-272. doi:10.26655/JJAEP.2019.10.1.

20. Prontenko K, Griban G, Medvedeva I et al. Interrelation of students' motivation for physical education and their physical fitness level. Inter J Appl Exer Physiol. . 2019; 8(2.1): 815-824. doi https://doi.org/10.30472/ijaep. v8i2.1.566.

21. SmolyarVI. Ratsionalnoe pitanie [Rational nutrition]. Kyiv: Naukova dumka; 1991: 368 .

22. Kosiba G, Gacek M, Wojtowicz A, Majer M. Level of knowledge regarding health as well as health education and pro-health behaviours among students of physical education and other teaching specializations. Baltic Journal of Health and Physical Activity. 2019;11(1):83-95. doi:10.29359/ BJHPA.11.1.09

23. Budagh'janc Gh.M.Zdorovyj sposib zhyttja - osnovna umova profilaktyky deviantnoji povedinky pidlitka (istorychnyj aspekt) [Healthy lifestyle - the main condition for the prevention of adolescent deviant behavior (historical aspect)]. Pedaghoghika, psykhologhija ta medyko-biologhichni problemy fizychnogho vykhovannja i sportu. 2010;6:25-28. (In Ukrainian).

24. Bojanic D, Vasiljevic I, Petkovic J, Muratovic A. Athletes' knowledge of reduced sports nutrition. Sport Mont. 2015;13(43-44-45):94-98.

25. Muntjan VS. Analyz faktorov, opredeljajushhykh zdorovj'e cheloveka y okazyvajushhykh na negho vlyjanyja [Analysis of factors that determine human health and influence it]. Fyzycheskoe vospytanye studentov. 2010;6: 44-47. (In Russian).

26. Health organization. Global strategy on diet, physical activity and health. Available from: http:// www.who.int/dietphysicalactivity/pa/en/. 
27. Griban GP. Osnovi harchuvannya. Teoriya ta praktichni zastosuvannya [Basics of nutrition. Theory and practical applications]. Zhytomyr: Ruta; 2010:882.

28. Zavydivska 0, Zavydivska N, Khanikiants 0 . Self-management as a condition for creating a health culture among students. J Phys Educ Sport. 2016;16(1):592597. doi:10.7752/jpes.2016.s1093.

29. Malimon 0, Volchinskiy A. Dinamika zahvoryuvanosti ta stanu zdorov'ya studentiv [Dynamics of student morbidity and health]. Fizichne vihovannya, sport i kultura zdorov'ya u suchasnomu suspilstvi. 2005;1:286-289. (In Ukrainian).

30. Makarov S, Stoyan N, Serheta I, Taran 0, Dyakova 0. Peculiarities of the interaction of the indicators of psychophysiological adaptation of modern students in the context of the effective monitoring of individual health of young women and young men. Wiad. Lek. 2019; 72 (5a):1053-1058.

31. Apanasenko GL. Knygha o zdorovj'e [Health Book]. Kyev: Medknygha; 2007:132. (In Russian).

32. Maglovanyi AV. Osnovy informacijnogho polja zdorov'ja osobystosti [Basics of information field of personality health]. Visnyk Chernighivsjkogho nacionaljnogho pedaghoghichnogho universytetu imeni T. Gh. Shevchenka. Serija: Pedaghoghichni nauky. Fizychne vykhovannja ta sport. 2010;81:285289. (In Ukrainian).

33. World Health Organization. Global recommendations on physical activity for health. Available from: http://www.who.int/dietphysicalactivity/factsheet_ recommendations.

34. Griban GP. Zhyttiediialnist ta rukhova aktyvnist studentiv [Life activity and mobility of students]. Zhytomyr: Ruta; 2009:594. (In Ukrainian).

35. Bolotin A, Bakayev V. Structure and content of the educational technology of managing students' healthy lifestyle. J Phys Edu Sport. 2015;15(3):362364. doi:10.7752/jpes.2015.03054.

36. Apanasenko G, Dolzhenko L. Rivenj zdorov'ja i fiziologhichni rezervy orghanizmu. [The level of health and physiological reserves of the organism]. Teorija i metodyka fizychnogho vykhovannja i sportu. 2007;1:17-21. (In Ukrainian).

37. Smolenskiy VL, Shibaeva LS. Pitanie sportsmenov [Nutrition for athletes]. Kyiv: Zdorovie. 1982:52. (In Russian).

38. Griban G, Dovgan N, Tamozhanska G et al. State of physical fitness of the students of ukrainian higher educational institutions. Inter J Applied Exer Physiol. 2020;9(5):16-26. Retrieved from http://www.ijaep.com/index. php/IJAE/article/view/975.

39. Mozolev 0, Khmara M, Shorobura I et al. Comparative analysis of the effectiveness of Polish and Ukrainian basic training programs in physical education for 9-10-year-old pupils. Univ J Educat Res. 2019;7(11):23452351. doi:10.13189/ujer.2019.071112.

40. Griban G, Tymoshenko 0, Arefiev V et al. (2020). The role of physical education in improving the health status of students of special medical groups. Wiad. Lek. 2020;73(3): 534-540. doi:10.36740/WLek202003125.
41. Prontenko K, Griban G, Bloshchynskyi I et al. Improvement of students' morpho-functional development and health in the process of sportoriented physical education. Wiad Lek. 2020;73(1):161-168. doi:10.36740/ WLek202001131.

42. Warburton D, Nicol CW, Bredin SS. D. Health benefits of physical activity: the evidence. Canadian Med Assoc J. 2006;174:801-809.

The work was carried out according to the plan of the research work of Zhytomyr Ivan Franko State University for 2014-2024 on the theme of "Theoretical and methodological bases of improving the educational process of physical education at higher educational institutions" (state registration number 0114U003978).

Received: 29.01.2021

Accepted: 23.02.2021

Conflict of interest:

The Authors declare no conflict of interest

\section{ADDRESS FOR CORRESPONDENCE: Grygoriy P. Griban}

Zhytomyr Ivan Franko State University

Zhytomyr, Ukraine

phone: +380973341092

e-mail: gribang@ukr.net

\section{ORCID ID and AUTHORS CONTRIBUTION}

0000-0002-9049-1485 - Grygoriy P. Griban (A, B) 0000-0001-8164-9706 - Vladyslav A. Smiianov (E, F)

0000-0003-0503-9935 - Natalia A. Lyakhova $(A, E)$

0000-0003-4407-8611 - Pavlo P. Tkachenko (B, C)

0000-0001-7859-8637 - Alla M. Harlinska (C, E)

0000-0002-4715-028X - Nadya Yu. Dovgan (B, D)

0000-0003-0271-9206 - Roman P. Karpiuk (F, E)

0000-0002-4071-5766 - Yurii A. Brytan (D)

A - Research concept and design, B - Collection and/or assembly of data, C - Data analysis and interpretation, $\mathrm{D}$ - Writing the article, $\mathrm{E}$ - Critical revision of the article, $\mathrm{F}$ - Final approval of article 


\section{Attachment 1.}

\section{QUESTIONNAIRE \\ for studying the students' nutritional status}

In order to study the nutritional status of students, we ask you to answers the questions, not missing any of them. The correctness of the conclusions will depend on the faithfulness of your answers. This will provide an opportunity to create new methodical and practical recommendations for improving the nutrition system at the higher education institution, to influence the range of food in the canteen. Your life experience, your knowledge of nutrition can make it more nutritious and balanced. It is not difficult to answer the questions. Each of them is provided with several possible answers. Read them, choose one and underline it. If none of the suggested answers is suitable, add your own. We left a space for this. The survey is anonymous. Your answers will be used in a generalized form for scientific purposes only. We hope for your help and we are sincerely grateful to you in advance.

- What is your gender? - male - female

- What is your year of study? - I - II - III - IV

- What is your educational department?

- special department - main department - sports department

- What is your age? - 17, - 18-20, - 21 or more

- What is your marital status? - married - not married

- What is your place of residence? -village - rural settlement - city

- Where did you get the secondary education?

- in a village school - in the city school - in a vocational-technical school - in a college

1. How often do you eat?

- 3-4 times a day

- 2 times a day

- at a certain time

- I do not eat breakfast

- I have dinner 2-3 hours before bedtime

- it depends, I do not stick to an eating schedule

2. Do you eat liquid food (soup)?

- 2 times a day - once a day - once every 2-3 days

- I rarely eat liquid food

3. Do you eat cold, very hot, or dry food?

- I try not to eat it - I eat it often

4. Do you eat fatty, bitter, sour, and over-salted food?

- I try not to eat it - I eat it often -

5. Do you eat sweets: sugar, candies, jams, cakes, pies?

- 3-4 times a day - 1-2 times a day - I try not to eat them

6. Do you drink strong tea or coffee?

- I do not drink them - once a day -2-3 times a day

7. Do you have good nutrition?

- yes - no - I cannot determine

8. Do you like to have a substantial meal?

- yes - no - sometimes when I am on a visit to somebody

9. Do you have a fasting day once a week?

- no -yes 
10. Do you follow a diet?

- no - yes why?

11. How often do you eat fresh fruit in the winter and how much?

- once a day - which ones? gram

- 2-3 times a day - which ones? gram

- as much as I want - which ones? gram

12. How often do you eat fresh vegetables in the winter and how much? - once a day - which ones? gram

-2-3 times a day - which ones? gram

- as much as I want - which ones? gram

13. Do you eat convenience food?

- yes - no

14. How often do you eat fish and seafood?
- once a day - 2-3 times a day
- 1 time every two days
-1-2 times a week - rarely

15. How often do you eat dairy products?
- once a day
- 2-3 times a day
- 1 time every two days
- 1-2 times a week
- rarely

16. Which cereals are dominant in your diet?
- buckwheat
- rice
- peas
- millet
- wheat grits
- pearl barley

\section{-}

17. How many times a day do you eat potatoes?
- not once
- 1 time
- 2 times
- 3 times or more

Thank you for participating in the survey! 